\title{
Artificial insemination services under different institutional framework in Bangladesh
}

\author{
MM Uddin ${ }^{1}$, M N Sultana ${ }^{1}$, G Van Huylenbroek ${ }^{2}$, KJ Peters $^{3}$ \\ ${ }^{1}$ Department of Animal Nutrition, Bangladesh Agricultural University, Mymensingh-2202, \\ Bangladesh; ${ }^{2}$ Department of Agricultural Economics, University of Ghent, Coupure Links 653, 9000 Ghent, \\ Belgium; \\ ${ }^{3}$ Department of Crop and Animal Science, Humboldt University of Berlin, Philip Str. 13, H-9, 10115 Berlin, \\ Germany
}

\begin{abstract}
The objective of the study was to compare the provision of the existing artificial insemination service delivery system (AI-SDS) among public, private and autonomous institutions to the small-scale dairy farmers in Bangladesh. A cross-sectional survey was conducted by using a pre-tested and pre-designed questionnaire and face-to-face interview technique. A stratified-purposive sampling technique was applied to select 165 small-scale dairy farmers from four study areas. Descriptive statistics were performed to know the frequency of the provision of Al services. Public services were available in all study areas whereas autonomous services were only delivered in Mymensingh district. The private service was increasing faster than the public and autonomous service. The public service had higher incentives and network coverage compared to private and autonomous services. The results also showed that $50 \%$ of the respondent perceived the Al service as "public goods" and showed no willingness to pay (e.g., free of charge for public service). The demand for the services has been increasing but the existing organizations were not able to provide the services especially to the remote areas. From this study, it is recommended that farmers' needs should be translated in a way that they get access to their required services in a satisfactory manner.
\end{abstract}

Key words: Artificial insemination, Institution and Organization, Service delivery System

Bangladesh Animal Husbandry Association. All rights reserved. Bang. J. Anim. Sci. 2014.43 (3): 166-174

\section{I ntroduction}

Livestock plays an important role in the national economy of Bangladesh. The share of the livestock sub-sector, in 2011, to the national gross domestic products (GDP) was $2.79 \%$, which was $16.5 \%$ of agricultural GDP (Bangladesh Economic Review, 2011). Dairying is an integral part of crop-livestock system and this is particularly important for the rural poor, including the functionally landless, many of whom regard livestock as a main livelihood option (Saadullah 2001; Uddin et al. 2011). About $75 \%$ of the rural people rely on livestock, particularly dairy, to some extent for their livelihood, which clearly indicates that the poverty reduction potential of the livestock sub-sector is high (DLS 2007; Upton 2011). Livestock development is considered an intermediate step to boost the overall economic development of the country and ensure the animal protein security.
To meet the growing demand and ensure adequate amount of protein from animal source and thus, food security at household level the famers need to increase their productivity. The existing low productive local cattle, low production of milk and meat and low investment in the sector are the major challenges towards improvement of livestock sector (Jabbar et al 2005; Khaleque et al. 2012). In addition, lack of appropriate breeds, suitable breeding policy and shortage of feeds and fodders throughout the year are also hindering the productivity (Bari 2008; Khan et al. 2009). The government intervention to overcome those problems by importing high yielding temperate breeds could not bring a solution to increase productivity. This instigates to search for alternative options; one of which is to infuse the exotic blood into the best local cows through either upgrading or crossbreeding. This leads to a key question: which tools are the best to implement upgrading 
or crossbreeding in order to enrich the genetic merit of the existing breeding stock and whether existing institutional framework are able to implement those tools at the farm level?

To answer to this question, artificial insemination services was considered as a significant vehicle to improve the existing reproductive performance of cattle breeds by implementing the cross-breeding (Uddin et al. 2010). Although the history of research into artificial insemination $(\mathrm{Al})$ is over two centuries old and its commercial application has now already span 75 years, in Bangladesh, Al has first been introduced just in 1959 during the then East Pakistan (Shamsuddin et al. 1987; Alam and Ghosh 1988). The extension as well as commercialization of $\mathrm{Al}$ service started and gained reputation in 1975 (Ali 2003). The prospect of $\mathrm{Al}$ continues to be promising reproductive technology due to three cornerstones of its application which are: it is simple, economical and successful (Vishwanath 2003). Although the immediate result of using Al is the impregnation of the female, the real benefit of using $\mathrm{Al}$ is that it gives all farmers the possibility of gaining from genetic improvements created elsewhere, privately or collectively.

In Bangladesh, Al services have been operated commercially by both government and private organizations whereas the autonomous organization provides the Al services within their research and extension strategy. All the government cattle breeding activities are performed by the DLS (Department of Livestock Service) - a base organization working under the Ministry of Fisheries and Livestock. The Al services are mainly delivered by District Artificial Insemination Centre. There are 23 centres covering the 64 districts of the country. Each centre has several sub-centre and Al points. All the district Al centres are coordinated by the Central Cattle Breeding Station (CCBS) located in Dhaka. There are 423 sub-centres and $554 \mathrm{Al}$ points. In addition, there is also private level Al activity which has been operating very recently. Until 2000, the provision of Al services for small holders has generally been only in the hands of government leading to erratic, insufficient and unreliable delivery system. In cases where the benefits of services accrue to the owner of the animals, privatization of the Al services may improve the delivery system. Due to the government recognition on the need the participation of the private sector in increasing service delivery system, the policy was liberalized in 2001 to allow private organization in the AlSDS. Within such policy, the private level Al activity has been operating after the signing the agreement between the government and BRAC (it was formerly called Bangladesh Rural Advancement Committee) in 2001. In contrast, the profit-oriented and exploitative role of the private sector has clearly articulated the need to have stronger regulatory bodies, institutional mechanisms that will facilitate the private investors to comply with institutions regarding the delivery of $\mathrm{Al}$ services mentioned in the agreement (DLS, 2001) for increasing the effective service delivery system to the smallscale farmers (Khalequ et al. 2012).

However, in order to open up the government policy to include private organizations in Al-SDS, the question arises as to which extent the provision of these services by private organizations is of comparable in terms of service area coverage, farmer's access, farmers affordability (e.g. economic benefit) and quality to that of public organizations. Therefore, it is necessary to conduct research on the provision of Al services across the organizational structure. Until now, no study has been documented in the literature that compares the services provision among the various organizations. Hence, the objective of this study is to compare the $\mathrm{Al}$ services delivery system (AI-SDS) among public, private and autonomous organizations.

\section{Materials and Methods}

This study was conducted in four districts such as Comilla, Brahmanbaria, Narayangonj and Mymensingh districts. The reasons for selection of these districts were due to the fact that each of the districts represents diverse characteristics in terms of demography, socio-economics, institutions and organizations, livestock production and agricultural farming systems. The district of Comilla represents the high density populated areas where the farmers have more dependence on off-farm activities. Regarding institutional perspectives, District Al Centre (DAIC)-a public organization for providing Al 


\section{Artificial Insemination Service Delivery System}

services to livestock farmers is situated in this district. The Brahmanbaria district is typically low-lying area where farmers depend mostly on rice production and fish culture as compared to livestock production. In relation to institutional perspectives, there is no DAIC in this district though it has $\mathrm{Al}$ sub-centres and $\mathrm{Al}$-points. The farming system of Narayangonj district represents the urban farming system where the farmers have more access to off-farm income than other three districts. The district of Mymensingh is different from other three districts because of the presence of both DAIC and autonomous Al service provider. Bangladesh Agricultural University (BAU), as an autonomous organization, is situated in this district and delivery the Al services to the neighbouring areas.

The data were collected from 165 farmers based on the criteria that each of the farmers had an equal option to access and use $\mathrm{Al}$ at least one of the three service providers. The stratifiedpurposive sampling technique was chosen pertaining data to fulfil the objectives of this study.The distribution of sampling farmers were as follows: Comilla: $n=40$ using both public and private, Brahmanbaria: $\mathrm{n}=30$ using both public and private, Narayangonj: $\mathrm{n}=35$ using both public and private, and Mymensingh: $n=60$ among them, $\mathrm{n}=35$ use state and $\mathrm{n}=25$ use autonomous services. The services provided by the DAIC was considered as public Al service, while the private Al service was provided by the BRAC-a Non-governmental organization. The autonomous service was provided by the BAU Al centre. However, the program for providing private Al services are limited to some areas due to an institutional agreement with the public organizations enabling the private Al services to operate only in the areas where public services were not reachable. In the present study, purposively private services that operate their services parallel with other providers were selected.

The data were collected with the help of a predesigned, pre-tested and structured standard questionnaire containing both open and closeended questions. The questionnaire was designed to cover three broad areas of information such as farm and farmer characteristics, information related to the provision of Al services and outcome/performance efficiency in public, private and autonomous organizations and information related with the governance structure.

The data were classified into three groups: public, private and autonomous in order to compare the provision of AI-SDS across different institutional arrangement. The key variables that were used to know the provision of Al-SDS were: Al service provision structure, trend of the service, level of incentives, transaction cost, service coverage, farmers' access to complain to the organization and their willingness to pay (WTP) especially for the public services. In addition, a number of farm specific socio-economic factors were also analyzed to understand the characteristics of the farmers and their farming system. The data collected from the personal interview were subjected to statistical analysis with SPSS statistical packages.

\section{Results}

\section{Farms and farmers characteristics}

The major variables that reflect the farmers' characteristics were the age, gender and level of education which are depicted in Table 1 . In terms of age structure, most of the farmers were between 45-60 years old that corresponds to $45.5 \%$ followed by $31-45$ years $(42.4 \%), 15-30$ years $(9.1 \%)$ and above 60 years $(3 \%)$. With regards to the gender, most of the farmers interviewed were male $(67.9 \%)$ whereas $32.1 \%$ represent the females involved in cattle farming. Concerning the level of education, the most of farmers (representing 48\%) have secondary education whereas $19 \%$ do not have any education.

Livestock, with particularly dairying, is integrated with crop production as $37 \%$ of the farmers produce only rice in addition of rearing livestock while $49 \%$ produces rice in a combination with wheat and vegetables. This indicates that the small-scale dairy farming systems are well integrated with on-farm and off-farm activities as shown in the lower part of the Table 1 . The same is reflected in the off-farm activities as only $94 \%$ of the farmers somehow involved other than dairy activities and receive an amount that varies as lower than 2000 to more than 12000 
BDT/year. Since dairying alone is not enough to meet the daily needs, farmers depend on offfarm activities. The farm size varies from 1-3 to $<10$ cows. Half of the farmers have a herd size of 1-3 and 25\% have 4-6 cattle per farm. This again reveals the relatively lower herd size of the smallscale farming system in Bangladesh.

Table 1. Characteristics of the farms and farmers in the study area

\begin{tabular}{|c|c|c|c|c|}
\hline $\begin{array}{l}\text { Characteristics } \\
\text { of }\end{array}$ & Variables & Category & Frequency & $\%$ \\
\hline \multirow{11}{*}{ Farmers } & \multirow{4}{*}{ Age } & $15-30$ years & 15 & 9.1 \\
\hline & & $31-45$ years & 70 & 42.4 \\
\hline & & $46-60$ years & 75 & 45.5 \\
\hline & & Above 60 years & 5 & 3.0 \\
\hline & \multirow{2}{*}{ Gender } & Male & 112 & 67.9 \\
\hline & & Female & 53 & 32.1 \\
\hline & \multirow{5}{*}{$\begin{array}{l}\text { Level of } \\
\text { Education }\end{array}$} & No education & 19 & 11.5 \\
\hline & & Primary & 44 & 26.7 \\
\hline & & Secondary & 48 & 29.1 \\
\hline & & $\begin{array}{l}\text { Higher } \\
\text { secondary }\end{array}$ & 34 & 20.6 \\
\hline & & University & 20 & 12.1 \\
\hline \multirow{17}{*}{ Farms } & \multirow{5}{*}{$\begin{array}{l}\text { Crop- } \\
\text { livestock } \\
\text { integration }\end{array}$} & No crop & 24 & 14.5 \\
\hline & & Rice only & 61 & 37.0 \\
\hline & & Rice + Wheat & 20 & 12.1 \\
\hline & & Rice+Vegetables & 16 & 9.7 \\
\hline & & $\begin{array}{l}\text { Rice + Wheat + } \\
\text { Vegetables }\end{array}$ & 44 & 26.7 \\
\hline & \multirow{8}{*}{$\begin{array}{l}\text { Off-farm } \\
\text { income }\end{array}$} & No income & 10 & 6.1 \\
\hline & & $<2000$ BDT* $^{*}$ & 37 & 22.4 \\
\hline & & $2000-4000$ BDT & 23 & 13.9 \\
\hline & & $4000-6000$ BDT & 27 & 16.4 \\
\hline & & 6000-8000BDT & 18 & 10.9 \\
\hline & & $8000-10000$ BDT & 17 & 10.3 \\
\hline & & $\begin{array}{l}10000-12000 \\
\text { BDT }\end{array}$ & 20 & 12.1 \\
\hline & & $>12000 \mathrm{BDT}$ & 13 & 7.9 \\
\hline & \multirow{4}{*}{$\begin{array}{l}\text { Number of } \\
\text { cattle }\end{array}$} & $1-3$ & 81 & 49.1 \\
\hline & & $4-6$ & 42 & 25.5 \\
\hline & & $7-9$ & 26 & 15.8 \\
\hline & & $>10$ & 16 & 9.7 \\
\hline
\end{tabular}

* $1 B D T=0.01 € ; n=165$

The provision of $\mathrm{Al}$ in different regions and organization

The Al services provided by the public, private and autonomous institutions and farmers access to those services are depicted in Table 2. The public and private services are available in most of the areas accounting to $63.6 \%$ whereas the autonomous service availability is strict to only in Mymensingh districts. While comparing Al service delivery among public, private and autonomous organization individually, it is also evident that public Al service dominates over the private and autonomous organization in all the areas. The public Al service corresponds to $84.8 \%$ (Author's calculation, is not shown) whereas the private and autonomous together corresponds $15.2 \%$.

Table 2. Farmers access to the Al service provision

\begin{tabular}{lcccccc}
\hline \multirow{2}{*}{ Location } & \multicolumn{2}{c}{$\begin{array}{c}\text { Pubic }+ \\
\text { Private }\end{array}$} & \multicolumn{2}{c}{$\begin{array}{c}\text { Public }+ \\
\text { Autonomous }\end{array}$} & \multicolumn{2}{c}{$\begin{array}{c}\text { Private + } \\
\text { Autonomous }\end{array}$} \\
\cline { 2 - 9 } & Frequency & $\%$ & Frequency & $\%$ & Frequency & $\%$ \\
\hline Comilla & 40 & 24.2 & $\mathrm{~N} / \mathrm{S}$ & $\mathrm{N} / \mathrm{S}$ & \\
Brahmanbaria & 24 & 14.5 & $\mathrm{~N} / \mathrm{S}$ & $\mathrm{N} / \mathrm{S}$ & \\
Narayangonj & 41 & 24.8 & $\mathrm{~N} / \mathrm{S}$ & $\mathrm{N} / \mathrm{S}$ & \\
Mymensingh & $\mathrm{N} / \mathrm{S}$ & 35 & 21.3 & $\mathrm{~N} / \mathrm{S}$ & \\
BAU & $\mathrm{N} / \mathrm{S}$ & 0 & 0 & 25 & 15.2 \\
Total & 105 & 63.6 & 35 & 21.2 & 25 & 15.2 \\
\hline
\end{tabular}

N/S, Services not available

Trend of service provision among the different organizations

An increasing trend of Al service provision as perceived by the respondent is observed for all three organizations (Figure 1 ). The highest increase in private organization $(60.6 \%)$ is followed by public (55\%) and autonomous $(45.6 \%)$. In contrast, about $19.4 \%$ of the farmers perceived that autonomous service provision is decreasing while a majority of the farmers still perceived a stable service provision accounting for 39, 34 and $35 \%$ for public, private and autonomous, respectively.

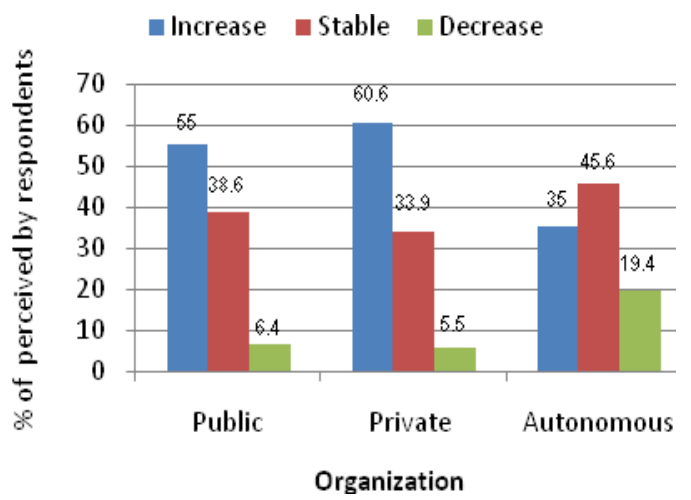

Figure 1. Trend of Al Services among the organizations 


\section{Artificial Insemination Service Delivery System}

\section{Provision of incentives for using Al services}

The incentives for using $\mathrm{Al}$ is defined by the additional support services that consist of the direct cash payment to the farmers or Al with follow up on the development of conception of the cows as well as diagnosis for reproductive diseases. The study revealed that state AI-SDS is accompanied with incentives of $45 \%$ varying from very high $(2.8 \%)$ to very low $(7.8 \%)$ (Table 3 ). On the other hand, most of the farmers receive no incentives ranging from $55 \%$ for state, $74 \%$ for private and $85 \%$ for autonomous organization.

Table 3. The provision of incentives perceived by the respondents among the organizations

\begin{tabular}{llcc}
\hline Organization & Incentives & Frequency & $\%$ \\
\hline \multirow{3}{*}{ Public } & Very high & 4 & 2.8 \\
& High & 3 & 2.1 \\
& Moderate & 21 & 14.9 \\
& Low & 24 & 17.0 \\
& Very low & 11 & 7.8 \\
& Nothing & 77 & 54.6 \\
\hline \multirow{3}{*}{ Private } & Very high & 1 & 1.0 \\
& High & 3 & 3.0 \\
& Moderate & 5 & 5.0 \\
& Low & 7 & 7.0 \\
& Very low & 10 & 10.0 \\
& Nothing & 74 & 74.0 \\
\hline \multirow{4}{*}{ Autonomous } & Very high & 0 & 0 \\
& High & 1 & 1.7 \\
& Moderate & 1 & 1.7 \\
& Low & 3 & 5.0 \\
& Very low & 4 & 6.7 \\
& Nothing & 51 & 85.0 \\
\hline
\end{tabular}

\section{Transaction costs for different organizations}

The extent of transaction costs (in terms of time/dose of Al service, money spent/hour and physical labour ( $\mathrm{km}$ walk/dose of Al service) incur during uptake of the Al service are depicted in Table 4. The level of transaction costs ranging from high to very high is evident as 74,87 and $100 \%$ for state, private and autonomous organization, respectively. The autonomous institutions rank the highest $(71.7 \%)$ transaction costs over private $(53.5 \%)$ and state $(47.1 \%)$. In case of public service, the high, moderate, low, very low transaction cost were found $38 \%, 29 \%$,
$4 \%, 3 \%$, respectively while those for private are $33 \%, 9 \%, 1 \%, 1 \%$, respectively.

Table 4. Transaction costs among the organizations

\begin{tabular}{llcc}
\hline Organization & Transaction & Frequency & $\%$ \\
\hline \multirow{3}{*}{ Public } & Very high & 66 & 47.1 \\
& High & 38 & 27.1 \\
& Moderate & 29 & 20.7 \\
& Low & 4 & 2.9 \\
& Very low & 3 & 2.1 \\
& No transaction costs & 0 & 0 \\
\hline \multirow{3}{*}{ Private } & Very high & 53 & 53.5 \\
& High & 33 & 33.3 \\
& Moderate & 9 & 9.1 \\
& Low & 1 & 1.0 \\
& Very low & 1 & 1.0 \\
& No transaction costs & 2 & 2.0 \\
\hline \multirow{5}{*}{ Autonomous } & Very high & 43 & 71.7 \\
& High & 17 & 28.3 \\
& Moderate & 0 & 0 \\
& Low & 0 & 0 \\
& Very low & 0 & 0 \\
& No transaction costs & 0 & 0 \\
\hline
\end{tabular}

$0=0 \%$ of the farmers have such transaction costs

\section{The Al service network coverage}

The distance from the farmer's home to the source of the Al service delivery center is represented in Figure 2 . The distance is measured by a radius of $8 \mathrm{~km}$ from the center (nearest to the peripheral). According to government policy, $100 \%$ of the respondent should receive $\mathrm{Al}$ services within this radius but from this study it has been observed that only $47.30 \%$ of farmers found the source of Al service within 8 square $\mathrm{km}$ in case of public Al-SDS whereas those for private and autonomous were $21.20 \%$ and $12.10 \%$, respectively. Moreover, $19.40 \%$ farmers found no source of Al service within even $8 \mathrm{Km}^{2}$.

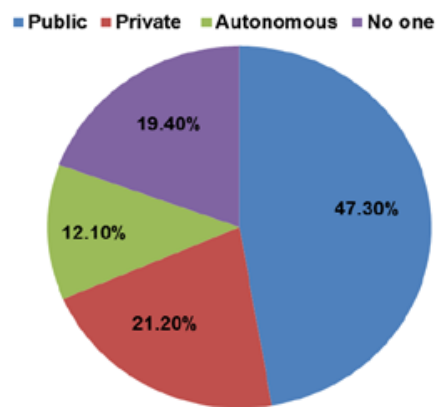


Figure 2. Availability of the Al service within $8 \mathrm{~km}^{2}$ among the organizations

The farmer's access to the AI-SDS and institutional willingness to accept the farmer's complain

The farmer's participation in the service delivery system is measured by the level of interaction between the service users (e.g. farmers) and service providers (e.g. Organization). One way to assess this is to measure the level of complexity the respondent faces in case the farmers willing to complain or to give overall feedback about their services. The nature and level of those complexities, is reported in Table 5. The present empirical study shows that 53,61 , and $70 \%$ of the farmers perceived very difficulties to access to the organization to complain for public, private and autonomous organization, respectively. Only a few of them (approximately 5-8\%) face no difficulties to reach to the organization.

Table 5. The nature of the complains among the different organization

\begin{tabular}{llcc}
\hline Organization & Nature of complain & Frequency & $\%$ \\
\hline \multirow{3}{*}{ Public } & Very difficult & 74 & 52.9 \\
& Difficult & 29 & 20.7 \\
& Moderate & 30 & 21.4 \\
& Easy & 7 & 5 \\
& Very easy & 0 & 0 \\
\hline \multirow{4}{*}{ Private } & Very difficult & 60 & 61.3 \\
& Difficult & 23 & 23.4 \\
& Moderate & 7 & 7.1 \\
& Easy & 5 & 5.1 \\
& Very easy & 3 & 3.1 \\
\hline \multirow{5}{*}{ Autonomous } & Very difficult & 42 & 70 \\
& Difficult & 12 & 20 \\
& Moderate & 6 & 10 \\
& Easy & 0 & 0 \\
& Very easy & 0 & 0 \\
\hline
\end{tabular}

$0,0 \%$ of the farmers can complain in such a way

The nature of the goods and services and farmers willingness to pay

The nature of the Al services perceived by the farmers and their willingness to pay for those services are depicted in Table 6 . The result revealed that $47 \%$ of the farmers perceived that Al should be public goods and should only be managed and deliver by the public body. This is also reflected their willingness to pay because about half of the respondents (49.7\%) showed no willingness to pay indicating the demand for free Al services from the public body. In contrast, half of the respondents are aware on the 'free goods' and hence, showed their willingness to pay a fee in order to avoid the free riders and improve the quality of the services.

Table 6. The farmers' perception on the nature of the goods related to $\mathrm{Al}$ and their willingness to pay

\begin{tabular}{llll}
\hline Variable & Category & Frequency & $\%$ \\
\hline Should Al be a "public goods" and & Yes & 79 & 47.87 \\
only done by Public sector? & No & 86 & 52.1 \\
\hline \multirow{2}{*}{ Should Al be free of charge? } & Yes & 82 & 49.7 \\
& No & 83 & 50.3 \\
\hline
\end{tabular}

\section{Discussion}

The effective delivery of Al services to the farmers is highly influenced by the farmer characteristics, the nature of the service provisions, the performance of the institution and organization (Uddin et al. 2010). The farm and farmers characteristics results are squarely matched by the study by Uddin et al (2011) who found the average age of the farmers between 35-55 years. The age structure clearly indicates young people are away from dairying and this might lead to problem of getting successors when the old people will go for retirement.

The farmers' characteristics are important aspects of selection of the Al services. Since the Al is an advanced technology over natural breeding the farmers need to be innovative to choose such an innovation. It has been observed that very young active population and very old which are considered as inactive population are not involved in farming activities. This could be due to the fact that a majority of the young population is either involved in higher studies or other businesses. Similarly the most of the old people are not physically so strong to run such cattle farming

In terms of gender, it is quite clear that most of the farmers were male. The reason for high percentage of males is that Bangladesh is a male dominated society where males are directly responsible for the income in the family. Although it seems that females are less in number but 


\section{Artificial Insemination Service Delivery System}

$32.1 \%$ of females involved in the cattle farming is not negligible, which indicates that they are also a very important labour force in the cattle farming especially for the smallholder farming system where there is no hired labour in farming. The low involvement of university graduates in cattle farming is due to the fact that they are more involved in off- farm jobs.

As concerns the herd size, most of the farmers are involved in small-scale cattle farming due to land and capital constraint. Most of the land is used for cereal and vegetable production. Due to heavy pressure on land, farmers are unable to allocate land for fodder production. In terms of crop production, as rice is the staple food of Bangladesh, farmers produce rice since they perceive that rice production has higher economic value than fodder in spite of promotion of several fodder production projects where it has clearly shown that fodder production provides better economic value than rice. The dependence of high percentage of farmers on off-farm income clearly indicates that, cattle husbandry does not generate sufficient income to cover family requirements.

Among the services provision, the public Al service corresponds to $84.8 \%$ whereas the private and autonomous together corresponds $15.2 \%$. The higher availability of state Al service in all of the study areas is mainly attributed to its institutional arrangement. The DAIC is situated in the district level which works as umbrella organization for delivery of this services through Upazilla (called sub-district) Livestock office (ULO), and Al-points (covers within $8 \mathrm{Km} 2$ from ULO. The relatively low availability of private Al services is due to the government institutional regulation which does not allow private service providers to delivery their services within $8 \mathrm{Km}^{2}$ (DLS 2001), more specifically where there already exist the public Al services. The least provision of autonomous Al service delivery is simply because only one institution, namely, Bangladesh Agricultural University having only one Al centers which is basically a research centre but also provides to some extent the Al services to the farmers.

Considering the overall trend of growth of services, Al services increases which might be due to the decreasing number of breeding bull due to high cost in one hand and on the other hand raising crossbred gives higher economic value than local cows. The probability of spreading vertical reproductive diseases is substantially higher in natural services (Vishanath 2003) which is only possible to overcome through use of Al. The increase use of $\mathrm{Al}$ is also observed in other areas of Bangladesh (I slam et al. 2010). However, the highest increase in private services, as it is expected, is due to the liberalization of Al service policy by the government (DLS 2001).

To keep the growing trend of Al services, farmers need to have incentives on their continuous use of Al services. In this regards, the State AI-SDS has better position as compared to private and autonomous which might be due to the government breed upgradation policy that is combined with the introduction of "Breed upgradation project through progeny testing project" which provides incentives to the selected farmers for using Al from state-run Al centers and maintain breeding records for the improvement of the cattle breed in Bangladesh (Khan and Uddin, 2012). In contrast, the lowest incentives provided by the autonomous organizations might be due to the fact that autonomous $\mathrm{Al}$ centre is mainly a research $\mathrm{Al}$ centre wherein the main objective is not to provide services to the livestock producers on commercial basis and hence do not have policy frame for provision of incentives.

However, transactions costs are the key player to keep the users satisfactory. This study revealed that farmers have no option to receive $\mathrm{Al}$ services from any of the organization without transaction cost (Table 4). The reasons for high transaction cost in case of autonomous service might be attributed to its institutional arrangement of on-center service delivery system. The farmers must have to travel a long way with their cows for insemination which accounts for the opportunity cost of one day labour in extreme case in addition of transport cost while in case of state and private services, the inseminators go to the house of the farmers on request over mobile phone although in that case they have to pay an extra fee which is relatively cheaper than spending whole day. 
Another key decision criterion to use Al services by the farmers is the network coverage. This study showed that none of the organization follows the boundary rules (see Figure 2). This may be due to the fact that private organization does not comply with boundary rules as specified by the agreement between government and private organization such as BRAC (DLS 2001; Uddin et al 2010). Interesting to note that this boundary rules are not effective in some of the study areas which may result of $21 \%$ and $12 \%$ for private and autonomous service provision within $8 \mathrm{~km} 2$ (Figure 2). This indicates the inefficient governance of the agreement and this has clearly articulated that this agreement has limitations in sanctioning other operators in case of non-compliance of the rules and providing services within territory of the public services.

However, the extent of the distances of the services availability with boundary, termed as the network coverage of the Al-SDS among the different organizations, is also important to consider with a view to improving the network coverage. While farmers are demanding for the nearest source for $\mathrm{Al}$, the existing institutional setting is not able to meet this needs which trigger the need for institutional reform and strengthening the governance to make effective implementation of the institutions in Al delivery systems. This entails government intervention and participation in the service delivery system. The artificial insemination center-as public infrastructure and the artificial insemination service as public or quasi-public or private goods necessitates the understanding of the knowledge of institutions and governance structure for increasing the performance of this service (Uddin et al. 2010).

In order to increase the farmers' participation in the Al-SDS, it is necessary to remove the difficulties of transmitting farmers complain and/or feedback on Al service by different organization. This will show a good indicator of "good governance" and "degree of bureaucracy", respectively in AI-SDS. This finding indicates that in short-term, farmers will continue to uptake those services where they face difficulties but in long-term, the farmers will behave as "opportunity seekers" or "free-riders" and will shift the service providers from existing one once available. This might affect sharply the effective service delivery and could be a cause of obstacle to improve the service.

Nevertheless, the farmers' willingness to pay is the key determinant for successful delivery of $\mathrm{Al}$ services. The perceived nature of the goods and services influence the decision of the farmers regarding the use of the $\mathrm{Al}$ services and their willingness to pay. Since this study revealed that almost half of the farmers are not willing to pay for government Al services, government might devise cost sharing mechanism which would enhance the farmers participation in the AI-SDS in one hand and on the other hand, the effectiveness of the AI-SDS will be improved in the context of Bangladesh.

\section{Conclusions}

This study results revealed that public service provisions are widely available while the private services are also expanding higher compared to other two service providers. In contrast the autonomous service provision is strict to only particular area. The existing AI-SDS from public, private and autonomous organizations are not in the line with the expectation of the farmers. The relatively lower incentives, higher transaction cost, poor network coverage, institutional barrier to make access to the farmer's complain about their services- all make the overall service provision inefficient which need to consider by the government for their policy recommendation. The role of the government and its intervention on AI-SDS is still cannot be avoided. The key role for the government would be to monitor and regulate all other services providers while also strengthen its own service network. Hence government should initiate to reform the institutions to incorporate the needs of the smallscale livestock producers. Therefore, government should also provide the conducive policy environment to integrate the public service with other service providers with a co parable and acceptable quality and thus can enhance the ways to strengthen the institutional role in the provision of Al services. 


\section{Artificial Insemination Service Delivery System}

\section{References}

Alam MGS, Gosh A (1988). Reproductive Performance in Cows: its Relation to Pairity and Season. Bangladesh Veterinary Journal, 22: 51-56.

Ali MA (2003). A Manual of Breed Up-gradation through Progeny Test Project. Central Cattle Breeding Station, Department of Livestock Services, Savar, Dhaka, Bangladesh.

Bari ME (2008). Action Plan for Dairy Development in Bangladesh. In: Dairy Workship on 'Designing Effective Country Specific Strategy for Dairy Development' Bangkok, Thailand.

Department of Livestock Services (DLS) (2001). Ministry of Fisheries and Livestock, Farmgate, Dhaka, Bangladesh.

Department of Livestock Services (DLS) (2007). National Livestock Development Policy, Ministry of Fisheries and Livestock, Bangladesh.

Islam KMA, Uddin MM, Sultana MN, Assaduzzaman M, Islam MN (2010). Distribution pattern and management practices of crossbred dairy cows in cooperative dairy production system in Bangladesh. Livestock Research and Rural Development, 22: 219.

Jabbar MA, Islam SME; Delgado C, Ehui S. Akanda MAl, Khan MI, Kamruzzaman MM (2005). Policy and scale factors influencing efficiency in dairy and poultry producers in Bangaldesh. Joint working papers by ILRI/SLP/BSMRAU.

Artificial insemination ( $\mathrm{Al}$ ) Services for cattle improvement in Bangladesh-what are the most important concerns? Policy briefPractical Action, Bangaldesh

Khaleque V, Shahid S, Begum A, Islam FU, Alauddin SM (2012). Privatization of Artificical inseminaiton (Al) Services for cattle improvement in Bangladesh-what are the most important concerns? Policy briefPractical Actions Bangladesh.
Khan MAS, Uddin E (2012). Recording System for Breeding and Production Performance of Dairy. In: $38^{\text {th }}$ International Committee for Animal Recording (ICAR) Session, Cork, Ireland.

Khan MJ, Peters KJ, Uddin MM (2009). Feeding strategy for improvement of dairy cattle in small holder farm in Bangaldesh. Bangladesh Journal of Animal Scienc, 38: 67-85

Saadullah M (2001). Smallholder dairy production and marketing in Bangaldesh. In: Smallholder dairy production and marketing -opportunities and constraints, Proceedings of South-South workshop held at National Dairy Development Board, Anand, India.

Shamsuddin M, Ahmed JU, Alam MGS (1987). Effect of age of semen on conception rate in cattle under farm condition. Bangladesh Veterinary J ournal, 21: 51-58.

Uddin MM, van Huylenbroeck G, Hagedorn, K, Sultana MN, Peters KJ (2010). Institutional and organizational issues in livestock services deliver in Bangladesh. Quarterly Journal of International Agriculture, 49: 111-125.

Uddin MM, Sultana MN, Alqaisi O, Ndambi OA, Hemme T, Peters KJ (2011). Milk production trends and dairy development in Bangaldesh. Outlook on Agriculture, 40: 263-271.

Upton M (2004). The role of livestock in economic development and poverty reduction. Propoor Livestock Policy Initiatives working paper. Food and Agricultural Organization, Rome, I taly.

Vishanath R (2003) Artificial Insemination, The State of the Art. Theriogenology, 59: 571584. 